\title{
Pengujian Keputusan Fiktif Positif Di Pengadilan Tata Usaha Negara
}

\author{
Desy Wulandari \\ PTUN dan Magister Ilmu Hukum Universitas Islam Indonesia Yogyakarta \\ Jln. Cik Di Tiro No. 1 Yogyakarta \\ wulandaridesi112@gmail.com
}

\begin{abstract}
Article 53 of Law Number 30 of 2014 on Government Administration (Law 30/2014) does not provide an explanation of the criteria for positive fictitious decisions/actions of Government Agencies and/or Officials, but rather authorizing the State Administrative Court to review the reports on positive fictitious decisions/actions. As a form of expansion of the object of disputes in the State Administrative Court, positive fictitious decisions/actions require in-depth study considering there are obstacles in their implementation as well as the review at the State Administrative Court. This writing intends to determine the criteria for positive fictitious action of Government Agencies and/or Officials and to find out how to test positive fictitious decisions / actions by the State Administrative Court. This is a normative legal research, in which the results indicate, first, the criteria for positive fictitious decisions/actions can be identified by exploring the principal elements in Law 30/2014 and in the Supreme Court Regulation Number 8 of 2017. Second, the examination of positive fictitious decisions/actions is by using applicable laws and regulations and general principles of good governance.
\end{abstract}

Key Words: Governtment, positive fictitious decisions/actions, state administrative court

\begin{abstract}
Abstrak
Ketentuan Pasal 53 Undang-Undang Nomor 30 Tahun 2014 tentang Administrasi Pemerintahan (UU 30/2014) tidak memberikan penjelasan tentang kriteria keputusan/tindakan fiktif positif Badan dan/atau Pejabat Pemerintahan, namun memberikan wewenang kepada Pengadilan Tata Usaha Negara untuk menguji permohonan adanya keputusan/tindakan fiktif positif. Sebagai bentuk perluasan objek sengketa di Peradilan Tata Usaha Negara, keputusan/tindakan fiktif positif memerlukan kajian mengingat dalam implementasinya terdapat kendala dalam pengujiannya di Pengadilan Tata Usaha Negra. Tulisan ini bermaksud untuk mengetahui kriteria tindakan fiktif positif Badan dan/atau Pejabat Pemerintahan dan untuk mengetahui bagaimana pengujian keputusan/tindakan fiktif positif oleh Pengadilan Tata Usaha Negara. Penelitian ini merupakan penelitian hukum yang bersifat normatif. Hasil penelitian menyimpulkan, pertama, kriteria keputusan/tindakan fiktif positif dapat diketahui dengan menggali unsur-unsur prinsip dalam UU 30/2014 dan dalam Peraturan Mahkamah Agung Nomor 8 Tahun 2017. Kedua, pengujian keputusan/tindakan fiktif positif menggunakan peraturan perundang-undangan yang berlaku dan asas-asas umum pemerintahan yang baik.
\end{abstract}

Kata-kata Kunci: Keputusan fiktif positif; pemerintahan; pengadilan tata usaha negara 


\section{Pendahuluan}

Sejak diundangkannya Undang-Undang Nomor 30 Tahun 2014 tentang Administrasi Pemerintahan, Pengadilan Tata Usaha Negara se-Indonesia telah melaksanakan pemeriksaan perkara fiktif positif dan menguji permohonan adanya keputusan fiktif positif. Ketentuan Pasal 53 Undang-Undang Nomor 30 Tahun 2014 tentang Administrasi Pemerintahan (UUAP) memberikan atribusi kewenangan bagi Pengadilan Tata Usaha Negara untuk menerima, memeriksa, memutus dan menyelesaikan perkara permohonan keputusan fiktif positif. Sekalipun keputusan fiktif bukan merupakan hal baru, karena telah diatur dalam Pasal 3 Undang-Undang Nomor 5 Tahun 1986 tentang Peradilan Tata Usaha Negara, namun Undang-Undang Nomor 30 Tahun 2014 mengaturnya kembali dengan akibat hukum yang berbeda yaitu setelah Undang-Undang Nomor 30 Tahun 2014 terhadap permohonan administrasi negara apabila dalam batas waktu yang ditentukan dalam peraturan dasarnya tidak ditindaklanjuti oleh Badan dan/ atau Pejabat Pemerintahan atau bersikap diam, maka Badan dan/ atau Pejabat Pemerintahan dianggap mengabulkan permohonan penerbitan keputusan/ tindakan tersebut dan keputusannya disebut keputusan fiktif positif.

Dalam kajian hukum administrasi negara, ada tiga jenis tindakan hukum pemerintahan yaitu melakukan perbuatan materiil (materiele daad), mengeluarkan peraturan (regeling) dan mengeluarkan keputusan/ketetapan (beschikking). Pada awalnya terhadap sikap diam pemerintah ini tidak dapat diajukan gugatan ke pengadilan karena tidak ada keputusan. Pada prinsipnya pemerintah tidak boleh mengambil manfaat dari sikap diamnya (I'administration ne peut beneficier de son inaction). ${ }^{1}$ Pengadilan baru berwenang memeriksa suatu sengketa apabila ada keputusan yang digugat dan gugatan diajukan dalam tenggang waktu sejak diberitahukan atau diumumkannya keputusan yang disengketakan tersebut. ${ }^{2}$ Akan tetapi pemerintah dapat menutup peluang mengajukan gugatan ke pengadilan dengan menolak mengambil keputusan. Keadaan ini dapat menutup peluang mendapat jawaban bagi orang perseorangan atau perusahaan tanpa batas waktu. Oleh karena itu keputusan implicit telah diciptakan. Tujuannya adalah setelah tenggang waktu tertentu dengan sendirinya timbul keputusan sehingga ada keputusan yang dapat digugat di pengadilan. ${ }^{3}$ Keputusan fiktif lahir sebagai sarana untuk memberikan ruang bagi publik agar dapat mengajukan gugatan ke

${ }^{1}$ Yurisprudensi Peradilan Administrasi Perancis: Keputusan Implisit dan Titik Singgung Antara Sanksi Pidana dan Sanksi Administrasi, hlm. 20.

${ }^{2}$ Ibid., hlm. 25.

3Ibid., hlm. 25. 
pengadilan. Mengapa diperlukan pengaturan tentang keputusan fiktif? Pertama Untuk melindungi pemohon, salah satu syarat hak konstitusional untuk mengajukan gugatan adalah adanya suatu peraturan perundang-undangan yang mengatur akibat sikap diam pemerintah terhadap permohonan. Kedua Pada dasarya hakim Peradilan Tata Usaha Negara menguji legalitas keputusan. Hal ini berarti hakim tidak boleh menggantikan kedudukan administrasi pemerintahan.

Tindakan pengabulan permohonan administrasi menjadi kewenangan Badan/Pejabat Tata Usaha Negara sepenuhya dan berada dalam ranah kebijakan Badan/Pejabat Tata Usaha Negara yang kemudian diformalkan melalui penerbitan Keputusan Tata Usaha Negara, sehingga tidak hanya Keputusan Tata Usaha Negara saja yang dapat diajukan gugatan namun juga setiap tindakan yang dilakukan dalam rangka persiapan, pembentukan serta pemenuhan keputusan tata usaha negara4. Menurut Hughes E. Owen, setiap tindakan administrasi (pemerintah) itu dapat digugat oleh warga Negara ke pengadilan ${ }^{5}$ (tindakantindakan administratif dalam segala bentuknya harus dicermati untuk memastikan bahwa tindakan-tindakan tersebut sesuai dengan konstitusi, khususnya berkenaan dengan perlindungan hak-hak asasi manusia. Kesewenangwenangan dan ketidakjujuran administrasi akan dibatalkan oleh pengadilan dan dimungkinkan bagi warga negara untuk mengajukan gugatan ke pengadilan melawan pemerintah).

Berlakunya Keputusan Tata Usaha Negara yang bersifat fiktif positif ini tidak bersifat otomatis dikarenakan perlunya mekanisme yang diatur dalam Pasal 53 ayat (4, 5, dan 6) Undang-Undang Nomor 30 Tahun 2014 tentang Administrasi Pemerintahan, pemohon mengajukan permohonan ke Pengadilan Tata Usaha Negara agar dikeluarkan putusan atas penerimaan permohonan. Pengadilan akan memeriksa paling lama 21 hari kerja sejak permohonan didaftarkan apakah permohonan tersebut beralasan hukum dikabulkan atau ditolak atau tidak dapat diterima. Meskipun Peraturan Mahkamah Agung Nomor 5 Tahun 2015 digantikan dengan Peraturan Mahkamah Agung Nomor 8 Tahun 2017, karena Peraturan Mahkamah Agung Nomor 5 Tahun 2015 ternyata belum memberikan panduan yang jelas bagi hakim dalam mengadili perkara permohonan untuk memperoleh putusan dan Peraturan Mahkamah Agung Nomor 8 Tahun 2017 mengatur secara rinci mengenai pedoman beracara untuk memperoleh putusan atas penerimaan permohonan guna mendapatkan keputusan dan atau tindakan Badan atau Pejabat Pemerintahan, namun dalam implementasinya masih

${ }^{4}$ Kartika Widya Utama, "Surat Keputusan Tata Usah Negara Yang Bersifat Fiktif Positif”, Jurnal Notarius, Edisi 08, Nomor 2, September 2015, hlm. 146.

${ }^{5}$ Hughes E Owen, Public Managemen and Administration, An Introduction, Martin's Press, London, UK,1994, hlm. 243. 
ditemukan problematika hukum dalam memeriksa dan memutus permohonan fiktif positif seperti dalam Putusan Nomor 19/P/FP/2016/PTUN.PLK, putusan Nomor: 10/P/FP/2018/PTUN SMD.

Untuk menguji permohonan keputusan fiktif positif perlu melihat sikap diamnya Badan dan/atau Pejabat Pemerintahan yang tidak menanggapi permohonan pemohon tidak semata-mata diartikan sebagai mengabulkan permohonan pemohon melalui celah keterlambatan pejabat melakukan pelayanan karena tidak semua urusan pemerintahan prinsip ini dapat diterapkan. Karenanya perlu faktor pemahaman terhadap keputusan fiktif positif itu sendiri dan cara pengujiannya karena bisa terjadi salah satu alasan sikap diam badan dan atau pejabat pemerintahan yang tidak menanggapi permohonan dan permohonan dianggap dikabulkan secara hukum (keputusan fiktif positif) karena keputusan semacam ini membawa konflik serta terganggunya kepentingan pihak ketiga.

Tidak semua objek permohonan penerimaan keputusan fiktif positif langsung bisa diuji secara konvensional. Apabila permohonan penerimaan keputusan fiktif positif tersebut diuji secara konvensional dan alasan sikap diam badan dan atau pejabat pemerintahan yang tidak menanggapi permohonan dan permohonan dianggap dikabulkan secara hukum (keputusan fiktif positif) karena keputusan semacam ini membawa konflik atau membahayakan kepentingan publik, terganggunya kepentingan pihak ketiga apakah tidak terlalu cepat bila pengujiannya oleh Pengadilan Tata Usaha Negara dilakukan secara konvensinal? Berdasarkan uraian tersebut, penulis bermaksud mengkaji secara lebih mendalam, mengenai bagaimana pengujian terhadap keputusan fiktif positif di Pengadilan Tata Usaha Negara.

\section{Rumusan Masalah}

Berdasarkan uraian tersebut, maka kajian ini merumuskan permasalahan sebagai berikut. Pertama, apa kriteria tindakan fiktif positif Badan dan/atau Pejabat Pemerintahan? dan Kedua, bagaimana pengujian keputusan fiktif positif di PTUN?

\section{Tujuan Penelitian}

Penelitian ini digunakan untuk menganalisa hal-hal sebagai berikut. Pertama, untuk mengetahui, dan memberikan gambaran mengenai keputusan fiktif positif yang merupakan tindakan hukum pemerintahan, telah dilakukan oleh Badan dan/atau Pejabat Pemerintahan. Kedua, untuk mengetahui manakala keputusan fiktif positif tersebut diajukan permohonan ke pengadilan, bagaimana pengujian terhadap permohonan keputusan fiktif positif oleh PTUN. 


\section{Metode Penelitian}

Penelitian ini termasuk penelitian hukum normatif (yuridis normatif) karena yang dikaji adalah hukum dikonsepsikan sebagai norma hukum.

\section{Hasil Penelitian dan Pembahasan}

\section{Pengertian Tindakan Fiktif Positif Badan dan/atau Pejabat Pemerintahan}

Negara Indonesia merupakan negara hukumyang menganut konsepsi welfare state (negara kesejahteraan) sebagaimana diisyaratkan dalam alinea keempat Pembukaan UUD 1945 dalam tujuan negaradan dalam Pasal 1 ayat (3) UUD 1945. Implikasinya negara diberi wewenang yang luas untuk campur tangan disegala lapangan kehidupan masyarakat dalam rangka bestuurzorg mewujudkan kesejahteraan umum. Campur tangan tersebut tertuang dalam ketentuan perundang-undangan, baik dalam bentuk undang-undang maupun peraturan pelaksanaan lainnya yang dilaksanakan oleh administrasi negara selaku alat perlengkapan negara yang menyelenggarakan tugas servis publik. ${ }^{6}$

Dalam negara hukum, setiap tindakan pemerintah dalam menjalankan tugas-tugas pemerintahan dan pembangunan atau dalam rangka merealisir tujuan negara harus memiliki dasar hukum atau dasar kewenangan. Dalam hukum administrasi dikenal dengan asas legalitas. Artinya setiap aktifitas pemerintah harus memiliki dasar pada peraturan perundang-undangan yang berlaku. Tanpa adanya dasar wewenang yang diberikan oleh suatu peraturan perundang-undanganyang berlaku, maka aparat pemerintah tidak memiliki wewenang yang dapat mempengaruhi atau mengubah keadaan atau posisi hukum warga masyarakatnya. ${ }^{7}$

Dalam praktek dan perkembangannya tindakan pemerintahan itu tidak semata-mata harus berdasarkan wewenang yang diberikan undang-undang atau peraturan perundang-undangan (wetmatigheid van bestuur) tetapi juga harus memperhatikan hukum yang berlaku (rechtmatigheid van bestuur). Dengan kata lain pelaksanaan tugas dan fungsi pemerintahan tidak semata-mata harus mendasarkan pada peraturan tertulis tetapi juga harus memperhatikan hukum tidak tertulis atau yang lazim dikenal dengan istilah asas-asas umum pemerintahan yang baik. ${ }^{8}$

'Sjachran Basah, Eksistensi dan Tolok Ukur Badan Peradilan Administrasi Negara di Indonesia, Alumni, Bandung, 1985, hlm. 3.

${ }^{7}$ Indroharto, Usaha Memahami Undang-Undang Tentang Peradilan Tata Usaha Negara, Buku I, Ghalia Indonesia, Sinar Harapan, Jakarta, 1993, hlm. 83.

${ }^{8}$ Ridwan, Tiga Dimensi Hukum Administrasi dan Peradilan Administrasi, FH UII Press, Yogyakarta, 2009, hlm. 41. 
Tugas dan fungsi pemerintahan harus berdasarkan wewenang karena pada saat pemerintah melaksanakan tugas dan fungsinya secara yuridis pemerintah melakukan perbuatan hukum (rechtshandelingen) yakni suatu tindakan yang berdasarkan sifatnya dapat menimbulkan akibat hukum tertentu atau suatu tindakan hukum adalah tindakan yang dimaksudkan untuk menciptakan hak dan kewajiban. ${ }^{9}$

Tanpa dasar peraturan perundang-undangan, tindakan hukum pemerintah akan dikategorikan sebagai tindakan hukum tanpa kewenangan (onbevoegd) dan dikategorikan sebagai tindakan yang tidak sah (onrechtmatig). ${ }^{10}$

Dalam Undang-Undang Nomor 30 Tahun 2014, Tindakan Pejabat Pemerintahan atau penyelenggara negara lainnya dalam melakukan dan/atau tidak melakukan perbuatan konkret/ faktual (materieele daad) dikenal dengan Tindakan Administrasi Pemerintahan (Tindakan), Pasal 1 angka 8 Undang-Undang Nomor 30 Tahun 2014 menyebutkan Tindakan Administrasi Pemerintahan yang selanjutnya disebut Tindakan adalah perbuatan Pejabat Pemerintahan atau Penyelenggara Negara lainnya untuk melakukan dan/atau tidak melakukan perbuatan konkret dalam rangka penyelenggaraan pemerintahan.

Dengan pemberlakuan Undang-Undang Nomor 30 Tahun 2014, kompetensi Peradilan Tata Usaha Negara selain memeriksa, mengadili dan memutus Perbuatan Badan dan/atau Pejabat Pemerintahan dalam mengeluarkan Keputusan Administrasi Pemerintahan/Keputusan Tata Usaha Negara (beschikkingsdaads) juga memeriksa, mengadili dan memutus Tindakan Pejabat Pemerintahan atau Penyelenggara Negara lainnya dalam melakukan dan/atau tidak melakukan perbuatan konkret/faktual (materieele daad).

Terminologi fiktif positif tidak disebutkan secara eksplisit dalam UndangUndang Administrasi Pemerintahan, istilah ini merupakan fiksi hukum yang digunakan untuk mempermudah konstruksi hukum dalam Pasal 53 UndangUndang Administrasi Pemerintahan. Fiksi hukum yang dianut dalam UndangUndang Administrasi Pemerintahan diam berarti mengabulkan (disebut keputusan/ tindakan fiktif positif).

Oswald Jansen, mensejajarkan fiktif positif dengan istilah lex (bahasa latin) dan silencio positivo (Spanyol), silent consent, fictious approval atau tacit authorization (Inggris). Sedangkan Mark Aronson, mendefinisikan administration inaction (dalam tradisi common law), sementara Eralda Mathasani Cani mendefinisikan sikap diam

${ }^{9}$ Ibid., hlm. 42.

${ }^{10} \mathrm{Ibid}$., hlm. 56. 
yang dimaknai sebagai suatu persetujuan indentik dengan maksim hukum di Zaman Romawi quitacet consentire videtur(silence implies consent). ${ }^{11}$

Pengertian istilah fiktif positif digunakan dan dikembangkan dari suatu konsep keadaan ketika otoritas administrasi pemerintahan berdiam diri tidak melayani (administrative inaction) atau bersikap tidak responsif (delaying services) sebagaimana seharusnya atas suatu permohonan warga masyarakat (citizen) yang diajukan kepadanya. ${ }^{12}$

Bersesuaian dengan asas accepti (fictum positiva), ketentuan Pasal 53 ayat (1, 2, dan 3) Undang-Undang Nomor 30 Tahun 2014 mengartikan fiktif positif norma hukum, menentukan batas waktu kewajiban bagi Badan dan/atau Pejabat Pemerintahan guna menetapkan Keputusan (KTUN) serta batas waktu kewajiban bagi Pejabat Pemerintahan untuk melakukan suatu tindakan dalam rangka penyelenggaraan pemerintahan. Jika ketentuan peraturan perundang-undangan tidak menentukan batas waktu kewajiban Badan dan/atau Pejabat Pemerintahan, maka Badan dan/atau Pejabat Pemerintahan wajib menetapkan dan/atau melakukan Keputusan dan/atau Tindakan dalam waktu paling lama 10 hari kerja setelah permohonan diterima secara lengkap oleh Badan dan/atau Pejabat Pemerintahan. Apabila dalam batas waktu dimaksud, Badan dan/atau Pejabat Pemerintahan tidak menetapkan Keputusan (KTUN) dan/atau Pejabat Pemerintahan tidak melakukan suatu Tindakan Konkret/Faktual, maka permohonan tersebut dianggap dikabulkan secara hukum, dinamakan Keputusan Fiktif Positif.

Sesuai dengan azas legalitas dalam negara hukum, maka semua tindakan hukum (recht handelingen) dan atau tindakan faktual (feitelijke handelingen), Badan dan/atau Pejabat Pemerintahan baik menyangkut kewenangan, prosedur dan substansi harus berdasarkan pada ketentuan peraturan perundang-undangan serta sesuai dengan Asas-asas Umum Pemerintahan yang Baik (AUPB).Badan dan/Pejabat Pemerintahan (jabatan) dapat melakukan tindakan hukum dan atau tindakan faktual, maka dengan demikian subyek hukum tidak hanya terbatas pada manusia (natuurlijke person), badan hukum perdata (rechtspersoon) yang merupakan subyek hukum dalam hubungan keperdataan, akan tetapi juga Badan dan/Pejabat Pemerintahan (jabatan) merupakan subyek hukum publik, karena dilekati dengan hak, kewajiban dan kewenangan tertentu. Dalam kedudukannya sebagai subyek hukum publik maka Badan dan/Pejabat Pemerintahan (jabatan) dapat melakukan tindakan hukum yang dapat menimbulkan hak dan kewajiban secara hukum.

${ }^{11 E n r i c o ~ S i m a n j u n t a k, H u k u m ~ A c a r a ~ P e r a d i l a n ~ T a t a ~ U s a h a ~ N e g a r a, ~ T r a n s f o r m a s i ~ d a n ~ R e f l e k s i, ~ S i n a r ~ G r a f i k a, ~}$ Jakarta, 2018, hlm. 145.

${ }^{12}$ Ibid., hlm. 145. 
Terkait dengan tindakan fiktif positif Badan dan/atau Pejabat Pemerintahan, undang-undang sudah menetapkan batasan-batasan tertulis, dan batasan tidak tertulis yakni asas-asas umum pemerintahan yang baik, dalam mengambil keputusan administrasi negara, namun Badan dan/atau Pejabat Pemerintahan tidak mengambil Keputusan Administrasi Negara berdasarkan pada batasan tertulis, undang-undang dan batasan tidak tertulis, asas- asas umum pemerintahan yang baik.

Menjadi kewajiban Badan dan/atau Pejabat Pemerintahan untuk menetapkan Keputusan dan/atau Tindakan Administrasi Pemerintahan yang dimohonkan sesuai dengan ketentuan peraturan perundang-undangan. Badan atau Pejabat TUN tidak boleh menolak untuk memberikan pelayanan kepada warga negara dengan alasan tidak ada undang-undang yang mengaturnya (iura officialibus consilia).13 Baik keputusan pengabulan maupun penolakan yang dilakukan oleh Pejabat/ Badan TUN harus sesuai dengan peraturan perundangundangan dan memenuhi Asas-Asas Umum Pemerintahan Yang Baik.14 Pemerintah tidak boleh menolak permohonan masyarakat jika peraturan tidak mengaturnya (Ius nosse imperium).

Pejabat pemerintahan atau organ pemerintahan merupakan fungsionaris jabatan pemerintahan yang bertindak untuk dan atas nama jabatan atau melaksanakan tugas, fungsi dan kewenangan yang melekat pada jabatan melakukan berbagai tindakan pemerintahan (bastuurshandelingen) dan membuat keputusan (beschikkingen). Pejabat Pemerintahan hanya dapat melakukan tindakan publik atas dasar undang-undang, yakni atas dasar kewenangan yang bersumber pada undang-undang yang diperoleh secara atribusi, delegasi dan mandat yang selanjutnya digunakan untuk melakukan tindakan hukum (rechtshandeling).

Dengan menggunakan tolok ukur kewenangan pemerintahan, maka kewenangan pemerintahan ini menjadi dasar keabsahan keputusan dan/tindakan pemerintahan. Menurut P. Nicolai, kewenangan adalah kemampuan untuk melakukan tindakan hukum tertentu yaitu tindakan-tindakan yang dimaksudkan untuk menimbulkan akibat hukum dan mencakup mengenai timbul dan lenyapnya akibat hukum. Hak berisi kebebasan untuk melakukan atau tidak melakukan tindakan tertentuatau menuntut pihak lain untuk melakukan tindakan

\footnotetext{
${ }^{13}$ Ridwan, Diskeresi dan Tanggungjawab Pemerintah, FH UII Press, Yogyakarta, 2014, hlm. 314.

${ }^{14}$ Kartika Widya Utama, "Surat Keputusan Tata Usah Negara Yang Bersifat Fiktif Positif”, Jurnal Notarius, Edisi 08 Nomor 2, September 2015, hlm. 147.
} 
tertentu, sedangkan kewajiban memuat keharusan untuk melakukan atau tidak melakukan tindakan tertentu. ${ }^{15}$

Menurut Bagir Manan, dalam bevoegdheid terkandung makna kemampuan untuk melakukan atau tidak melakukan sesuatu berdasarkan suatu atau beberapa ketentuan hukum. Dalam bevoegdheid perbuatan melakukan atau tidak melakukan bukan untuk dirinya sendiri tetapi ditujukan kepada orang lain seperti wewenang memerintah dan wewenang mengatur. ${ }^{16}$

Ridwan menyatakan bahwa wewenang pemerintahan adalah keseluruhan hak dan kewajiban yang diberikan kepada organ pemerintah untuk melakukan berbagai tindakan hukum pemerintahan yakni tindakan-tindakan yang menimbulkan akibat hukum di bidang pemerintahan. ${ }^{17}$ Kewenangan dan wewenang diartikan berbeda dalam Undang-Undang Nomor 30 Tahun 2014. Pasal 1 Angka 5 Undang-Undang Nomor 30 Tahun 2014 mengartikan wewenang dengan hak yang dimiliki oleh Badan dan/atau Pejabat Pemerintahan atau Penyelenggaran Negara lainnya untuk mengambil keputusan dan/atau tindakan dalam penyelenggaraan pemerintahan. Sedangkan kewenangan dalam Pasal 1 angka 6 Undang-Undang Nomor 30 Tahun 2014 diartikan sebagai kekuasaan Badan dan/atau Pejabat Pemerintahan atau Penyelenggara Negara lainnya untuk bertindak dalam ranah hukum publik.

Lebih lanjut mengatur hak dan kewajiban yang diberikan kepada organ pemerintah untuk melakukan berbagai tindakan hukum pemerintahan, diatur dalamPasal 6 Ayat (1) Undang-Undang Nomor 30 Tahun 2014 Pejabat Pemerintahan memiliki hak untuk menggunakan kewenangan dalam mengambil keputusan dan/atau tindakan. Selanjutnya pada ayat (2) Hak sebagaimana dimaksud pada ayat (1) meliputi:

a. Melaksanakan kewenangan yang dimiliki berdasarkan ketentuan peraturan perundang-undangandan AUPB;

b. Menyelenggarakan aktivitas pemerintahan berdasarkan kewenangan yang dimiliki;

c. Menetapkan keputusan berbentuk tertulis atau elektronis dan/atau menetapkan tindakan;

d. Menerbitkan atau tidak menerbitkan, mengubah, mengganti,mencabut, menunda dan/atau membatalkan keputusan dan/atau tindakan;

e. Menggunakan Diskresi sesuai dengan tujuannya;

f. Mendelegasikan dan memberikan mandat kepada pejabat pemerintahan lainnya sesuai dengan ketentuan peraturan perundang-undangan;

\footnotetext{
${ }^{15}$ Ridwan, Urgensi Upaya Administrasi Di Indonesia, Cetakan Pertama, FH UII Press, Yogyakarta, 2019, hlm. 51. ${ }^{16}$ Bagir Manan, Perkembangan UUD 1945, FH UII Press, Yogyakarta, 2004, hlm. 59-60.

${ }^{17}$ Ridwan, Diskresi..., Op. Cit., hlm. 114.
} 
g. Menunjuk pelaksana harian atau pelaksana tugas untuk melaksanakan tugas apabila pejabat definitif berhalangan;

h. Menerbitkan izin,dispensasi dan/atau konsesi sesuai dengan ketentuan peraturan perundang-undangan;

i. Memperoleh perlindungan hukum dan jaminan keamanan dalam melaksanakan tugasnya;

j. Memperoleh bantuan hukum dalam pelaksanaan tugasnya;

k. Menyelesaikan sengketa kewenangan dilingkungan atau wilayah kewenangannya;

1. Menyelesaikan upaya administrasi yang diajukan masyarakat atas keputusan dan/atau tindakan yang dibuatnya; dan

m.Menjatuhkan sanksi administratif kepada bawahan yang melakukan pelanggaran sebagaimana diatur dalam Undang-Undang ini.

Selanjutnya kewajiban Badan dan/atau Pejabat Pemerintahan tercantum pada Pasal 7 Undang-Undang Nomor 30 Tahun 2014 tentang Administrasi Pemerintahan. Pasal 7 ayat (1): Pejabat pemerintahan berkewajiban untuk menyelenggarakan administrasi pemerintahan sesuai dengan ketentuan peraturan perundang-undangan, kebijakan pemerintahan, dan AUPB. Pada ayat (2): Pejabat pemerintahan memiliki kewajiban:

a. Membuat keputusan dan/atau tindakan sesuai dengan kewenangannya;

b. Mematuhi AUPB sesuai dengan ketentuan peraturan perundangundangan.

c. Mematuhi persyaratan dan prosedur pembuatan keputusan dan/atau tindakan;

d. Mematuhi undang-undang ini dalam menggunakan diskresi;

e. Memberikan bantuan kedinasan kepada badan dan/atau pejabat pemerintahan yang meminta bantuan untuk melaksankan penyelengggaraan pemerintahana tertentu;

f. Memberikan kesempatan kepada warga masyarakat untuk didengar pendapatnya sebelum membuat keputusan dan/atau tindakan sesuai dengan ketentuan peraturan perundang-undangan;

g. Memberitahukan kepada warga masyarakat yang berkaitan dengan keputusan dan atau tindakan yang menimbulkan kerugian paling lama 10 (sepuluh) hari kerja terhitung sejak keputusan dan/atau tindakan ditetapkan dan/atau dilakukan;

h. Menyusun standard operasional prosedur pembuatan keputusan dan/atau tindakan;

i. Memeriksa dan meneliti dokumen administrasi pemerintahan serta membuka akses dokumen administrasi pemerintahan kepada warga masyarakat, kecuali ditentukan lain oleh undang-undang;

j. Menerbitkan keputusan terhadap permohonan warga masyarakat, sesuai dengan hal-hal yang diputuskan dalam keberatan/banding; 
k. Melaksanakan keputusan dan/atau tindakan yang sah dan keputusan yang telah dinyatakan tidak sah atau dibatalkan oleh pengadilan, pejabat yang bersangkutan, atau atasan pejabat; dan

1. Mematuhi putusan pengadilan yang telah berkekuatan hukum tetap.

Dengan menggunakan tolok ukur kewenangan pemerintahan yang melekat pada jabatan pemerintahan sebagai subyek hukum, jabatan pemerintahan melalui organ pemerintahan yang melakukan tindakan pemerintahan dan membuat keputusan yang menjadi objek sengketa di Peradilan Administrasi.

Ketika kewenangan itu digunakan tidak sesuai dengan tujuan dilekatkannya kewenangan pada jabatan berarti terjadi penyalahgunanan wewenang dengan parameter asas spesialitas asas yang mengandung makna bahwa setiap pemberian wewenang memiliki tujuan tertentu. Menyimpang dari tujuan pemberian wewenang berarti terjadi penyalahgunaan wewenang.

Setiap pelaksanaan tugas dan fungsi pemerintahan harus berdasarkan wewenang karena pada saat pemerintah melaksanakan tugas dan fungsinya secara yuridis, saat itu pemerintah sedang melakukan perbuatan hukum (rechtshandelingen) yakni sutu tindakan yang berdasarkan sifatnya dapat menimbulkan akibat hukum tertentu ${ }^{18}$, atau suatu tindakan hukum adalah tindakan yang dimaksudkan untuk menciptakan hak dan kewajiban ${ }^{19}$.

Berdasarkan kewenangan yang diberikan oleh peraturan perundangundangan, maka pemerintah melakukan berbagai tindakan hukum pemerintah. Dalam perspektif hukum publik tindakan hukum pemerintah dituangkan dalam dan dipergunakan beberapa instrument hukum dan kebijakan seperti peraturan perundang-undangan (regeling), peraturan kebijakan (beleids) dan keputusan (beschikking). ${ }^{20}$

Indroharto membedakan tindakan pemerintah menjadi tiga hal dengan menyebutkan instrument pemerintahan yang paling banyak digunakan oleh Badan dan/atau Pejabat TUN itu berupa perbuatan/tindakan hukum menurut hukum publik (hukum tata negara atau hukum tata usaha negara), kemudian tindakan hukum menurut hukum perdata, dan disamping itu juga berupa perbuatan materiil. ${ }^{21}$ Perbuatan materiil menurut Pasal 1 angka 8 UndangUndang 30 Tahun 2014 dikenal dengan Tindakan Administrasi Pemerintahan (tindakan): Tindakan Administrasi Pemerintahan yang selanjutnya disebut Tindakan adalah perbuatan Pejabat Pemerintahan atau Penyelenggara Negara lainnya untuk

${ }^{18}$ RJHN. Huisman dikutip Ridwan, Tiga..., Op. Cit., hlm. 42

${ }^{19}$ JBJM Ten Berge dikuti Ridwan, Tiga ..., Op. Cit., hlm. 42.

${ }^{20}$ Ridwan HR, Hukum Administrasi Negara, UII Press, Yogyakarta, 2003, hlm. 340-341.

${ }^{21}$ Indroharto, Perbuatan Pemerintah Menurut Hukum Publik. Dan Hukum Perdata, LPP HAN, Jakarta, 1999 , hlm. 65-66. 
melakukan dan/atau tidak melakukanperbuatan konkret dalam rangka penyelenggaraan pemerintahan.Dalam pasal tersebut dapat diketahui ada 2 jenis perbuatan pemerintah: yaitu Pertama, melakukan perbuatan konkret; dan Kedua, tidak melakukan perbuatan konkret.Tidak melakukan perbuatan konkret maksudnya adalah tindakan yang dilakukan pemerintah itu bersifat fiktif atau tindakan fiktif yang berarti diam. Tindakan fiktif pemerintah tersebut ada yang bernada negatif maupun positif. Yang bernada positif berarti tindakan diam maksudnya penerimaan dalam Pasal 53 ayat (1) Undang-Undang Nomor 30 Tahun 2014.

Berdasarkan pada doktrin hukum dan peraturan perundang-undangan bahwa tindakan fiktif positif merupakan tindakan hukum pemerintahan berdasarkan hukum dan azas-azas umum pemerintahan yang baik, menimbulkan akibat hukum dibidang pemerintahan dan menjadi kewajiban Badandan/atau Pejabat Pemerintahan untuk menetapkan Keputusan dan/atau melakukan Tindakan Administrasi Pemerintahan yang dimohonkan sesuai dengan ketentuan peraturan perundang-undangan karena merupakan ruang lingkup penyelenggaraan pemerintahan dan merupakan ruang lingkup kewenangan pejabat, dengan batas waktu kewajiban bagi Pejabat Pemerintahan untuk melakukan suatu tindakan dalam rangka penyelenggaraan pemerintahan. Jika ketentuan peraturan perundang-undangan tidak menentukan batas waktu kewajiban Badan dan/atau Pejabat Pemerintahan, maka Badan dan/atau Pejabat Pemerintahan wajib menetapkan dan/atau melakukan Keputusan dan/atau Tindakan dalam waktu paling lama 10 hari kerja setelah permohonan diterima secara lengkap oleh Badan dan/atau Pejabat Pemerintahan. Apabila dalam batas waktu dimaksud, Badan dan/atau Pejabat Pemerintahan tidak menetapkan Keputusan (KTUN) dan/atau Pejabat Pemerintahan tidak melakukan suatu Tindakan Konkret/Faktual, maka permohonan tersebut dianggap dikabulkan secara hukum (Keputusan Fiktif Positif).

\section{Kriteria Tindakan Fiktif Positif Badan dan atau Pejabat Tata Usaha Negara}

Ketentuan Pasal 53 Undang-Undang Nomor 30 Tahun 2014 tidak memberikan penjelasan kriteria tindakan fiktif positif Badan dan/atau Pejabat Tata Usaha Negara. Ketentuan Pasal 53 Undang-Undang Nomor 30 Tahun 2014 menyebutkan, sebagai berikut.

1. Batas waktu kewajiban untuk menetapkan dan/atau melakukan Keputusan dan/atau Tindakan sesuai dengan ketentuan peraturan perundang-undangan.

2. Jika ketentuan peraturan perundang-undangan tidak menentukan batas waktu kewajiban sebagaimana dimaksud pada ayat (1) maka Badan 
dan/atau Pejabat Pemerintahan wajib menetapkan dan/atau melakukan Keputusan dan/atau Tindakan dalam waktu paling lama 10 (sepuluh) hari kerja setelah permohonan diterima secara lengkap oleh Badan dan/atau Pejabat Pemerintahan.

3. Apabila dalam batas waktu sebagaimana dimaksud pada ayat (2) Badan dan/ atau Pejabat Pemerintahan tidak menetapkan dan/atau melakukan Keputusan dan/atau Tindakan maka permohonana tersebut dianggap dikabulkan secara hukum.

4. Pemohon mengajukan permohonan kepada Pengadilan untuk memperoleh putusan penerimaan permohonan sebagaimana dimaksud pada ayat (3).

5. Pengadilan wajib memutuskan permohonan sebagaimana dimaksud pada ayat (4) paling lama 21 (dua puluh satu) hari kerja sejak permohonan diajukan.

6. Badan dan/atau Pejabat Pemerintahan wajib menetapkan Keputusan untuk melaksanakan putusan Pengadilan sebagaimana dimaksud pada ayat (5) paling lama 5 (lima) hari kerja sejak putusan Pengadilan ditetapkan.

Lebih lanjut dijelaskan, bahwa ketentuan Pasal 53 Undang-Undang Nomor 30 Tahun 2014 harus dilihat secara utuh, sebagai satu kesatuan antara ayat (1, 2, 3, 4, 5, dan 6). Apabila ketentuan Pasal 53 Undang-Undang Nomor 30 Tahun 2014 dilihat secara utuh sebagai satu kesatuan ${ }^{22}$, maka dapat ditarik unsur-unsur sebagai berikut.

1. Adanya kewajiban Badan dan/atau Pejabat Pemerintahan menetapkan Keputusan.

2. Batas waktu kewajiban Badan dan/atau Pejabat pemerintahan menetapkan Keputusan.

3. Adanya kewajiban Pemohon untuk pemenuhan kelengkapan persyaratan-persyaratan administratif, sebagai persyaratan untuk dapat diproses selanjutnya oleh Badan dan/atau Pejabat Pemerintahan.

4. Untuk mendapatkan keputusan dari Badan dan/atau Pejabat Pemerintahan yang berwenang dimaksud.

5. Adanya keharusan Badan dan/atau Pejabat Pemerintahan untuk menetapkan Keputusan.

6. Permohonan putusan penerimaan (fiktif positif) kepada pengadilan.

7. Batas waktu kewajiban pengadilan memutuskan permohonan putusan penerimaan;

8. Kewajiban Badan dan/ atau Pejabat Pemerintahan untuk melaksanakan Putusan Pengadilan.

22Putusan Mahkamah Konstitusi Republik Indonesia dalam Richard Chistoforus Massa, Nomor 77/PUUXV/2017, hlm. 40 . 
Berdasarkan unsur-unsur prinsip pada Pasal 53 Undang-Undang Nomor 30 Tahun 2014, Badan dan/atau Pejabat Pemerintahan yang berwenang sebelum mengambil keputusan fiktif positif, melakukan proses administratif yaitu validasi kelengkapan persyaratan administratif dari Pemohon. Kelengkapan persyaratan administratif untuk diterima sebagai dokumen yang dapat dinyatakan lengkap, sebagaimana dipersyaratkan, harus memenuhi syarat formal dan material mengenai objek yang akan diajukan permohonan secara transparan.

Persyaratan administrasi dinyatakan lengkap apabila semua persyaratan yang ada terpenuhi, dan persyaratan tersebut tidak bermasalah, artinya tidak ada lagi kaitannya dengan pihak lain secara hukum. Apabila dalam proses pemeriksaan dan/atau validasi formal dan material ditemukan terdapat ketidaksesuaian atau kategori tidak bersih maka sudah tentu Badan dan/atau Pejabat Pemerintahan tidak akan menyatakan lengkap persyaratan dan tidak menerima permohonan dimaksud. Implikasinya proses pelayanan dan/atau permohonan tidak dapat dilanjutnya.

Apabila persyaratan administrasi terpenuhi secara lengkap Badan dan/atau Pejabat Pemerintahan dapat melanjutkan fungsinya melakukan tahapan selanjutnya sesuai peraturan perundang-undangan yang berlaku dan asas-asas umum pemerintahan yang baik, dengan penerimaan syarat administratif dalam kode kategori lengkap artinya dapat dipertanggungjawabkan sesuai dengan Pasal 53 ayat (2) Undang-Undang Nomor 30 Tahun 2014. Jika ketentuan peraturan perundang-undangan tidak menentukan batas waktu kewajiban sebagaimana dimaksud pada ayat (1) maka Badan dan/atau Pejabat Pemerintahan wajib menetapkan dan/atau melakukan Keputusan dan/atau Tindakan dalam waktu paling lama 10 hari kerja setelah permohonan diterima secara lengkap oleh Badan dan/atau Pejabat Pemerintahan.

Kelengkapan persyaratan yang telah dinyatakan lengkap oleh Badan dan/Pejabat Pemerintahan merupakan prasyarat bagi Badan dan/atau Pejabat Pemerintahan menetapkan keputusan.Pengadilan diberikan kewenangan untuk memutus sesuai Pasal 53 ayat (5) Undang-Undang Nomor 30 Tahun 2014 terhadap permohonan Pemohon sebagai kelanjutan dari proses administrasi untuk mendapatkan penguatan keputusan dan/atau tindakan dari Badan dan/atau Pejabat Pemerintahan berdasarkan permohonan yang didukung syarat administrasi lengkap baik syarat formal maupun syarat materiil. Pengadilan diberi kewenangan untuk memberikan legitimasi terhadap putusan berdasarkan fiktif positif dimaksud, dalam rentang waktu 21 hari kerja sejak permohonan diajukan dengan melakukan pendalaman terhadap permohonan yang diajukan, 
karena proses administrasi Badan dan/atau Pejabat Pemerintahan yang berwenang sudah menyatakan lengkap dan tidak bermasalah lagi terhadap objek yang dimohonkan sehingga pengadilan hanyalah menerima, memeriksa dan memutus permohonan. ${ }^{23}$

Pengertian objek permohonan dan kriteria permohonan diatur dalam Pasal 3 Peraturan Mahkamah Agung Republik Indonesia Nomor 8 Tahun 2017 menyebutkan:

(1)Objek permohonan guna mendapatkan keputusan dan/atau tindakan badan dan/atau pejabat pemerintahan adalah kewajiban badan dan/atau pejabat pemerintahan untuk menetapkan keputusan dan/atau melakukan tindakan administrasi pemerintahan yang dimohonkan sesuai dengan ketentuan peraturan perundang-undangan.

(2)Kriteria permohonan guna mendapatkan keputusan dan/atau tindakan badan dan/atau pejabat pemerintahan yaitu:

a. Permohonan dalam lingkup kewenangan badan dan/atau pejabat pemerintahan;

b. Permohonan terhadap keputusan dan/atau tindakan untuk menyelenggarakan fungsi pemerintahan;

c. Permohonan terhadap keputusan dan/atau tindakan yang belum pernah ditetapkan dan/atau dilakukan oleh badan dan/atau pejabat pemerintahan; dan

d. Permohonan untuk kepentingan pemohon secara langsung.

(3)Tidak termasuk objek Permohonan yang dapat diajukan ke Pengadilan, sebagai berikut:

a. Permohonan merupakan pelaksanaan dari Putusan Pengadilan yang berkekuatan hukum tetap; atau

b. Permohonan terhadap permasalahan hukum yang sudah pernah diajukan gugatan.

Ketentuan Pasal 3 ayat (2) Perma Nomor 8 Tahun 2017 merupakan kriteria dalam menentukan tindakan fiktif positif Badan dan/atau Pejabat Pemerintahan yaitu apakah permohonan yang diajukan permohonan dalam lingkup kewenangan Termohon dalam lingkup menyelenggarakan fungsi pemerintahan, serta permohonan terhadap keputusan dan/atau tindakan yang belum pernah ditetapkan dan/atau dilakukan oleh badan dan/atau pejabat pemerintahan dan Permohonan untuk kepentingan pemohon secara langsung sehingga Badan dan/atau Pejabat Pemerintahan memiliki kewenangan, hak, kewajiban untuk menetapkan keputusan dan/atau tindakan hukum pemerintahan dalam rangka penyelenggaraan pemerintahan.

${ }^{23}$ Ibid., hlm. 40-45. 
Muchsan ${ }^{24}$ menyebutkan unsur-unsur tindakan hukum pemerintah manakala:

a. Perbuatan itu dilakukan oleh aparat pemerintah dalam kedudukannya sebagai penguasa maupun sebagai alat perlengkapan pemerintahan (bestuurorganen) dengan prakarsa dan tanggung jawab sendiri.

b. Perbuatan tersebut dilaksanakan dalam rangka menjalankan fungsi pemerintahan.

c. Perbuatan tersebut dimaksudkan sebagai sarana untuk menimbulkan akibat hukum dibidang hukum administrasi.

d. Perbuatan yang bersangkutan dilakukan dalam rangka pemeliharaan kepentingan negara dan rakyat.

Unsur-unsur ini perlu ditambahkan. Dalam suatu negara hukum setiap tindakan hukum pemerintahan selalu harus didasarkan pada asas legalitas atau harus berdasarkan peraturan perundang-undangan yang berlaku..$^{25}$

Indroharto membedakan tindakan pemerintah menjadi tiga hal dengan menyebutkan instrument pemerintahan yang paling banyak digunakan oleh Badan dan/atau Pejabat TUN itu berupa perbuatan/tindakan hukum menurut hukum publik (hukum tata negara atau hukum tata usaha negara), kemudian tindakan hukum menurut hukum perdata, dan di samping itu juga berupa perbuatan materiil. ${ }^{26}$

Dalam Hukum Administrasi ada 3 macam penggolongan perbuatan tata usaha negara (bestuurshandeling):

1. Perbuatan Tata Usaha Negara dalam mengeluarkan Keputusan/ Keputusan Tata Usaha Negara (beschikkingsdaad van de administratie);

2. Perbuatan Tata Usaha Negara dalam membuat dan mengeluarkan Peraturan (regelend daad van de administratie).

3. Perbuatan Materiil Tata Usaha Negara (materieele daad van de administratie).

Dalam undang-undang Peratun, kompetensi absolut Pengadilan Tata Usaha Negara adalah memeriksa, mengadili dan memutus perbuatan tata usaha negara dalam mengeluarkan Keputusan/ Keputusan Tata Usaha Negara (beschikkingsdaad van de administratie). Dengan pemberlakuan Undang-Undang Nomor 30 Tahun 2014, kompetensi Peradilan Tata Usaha Negara adalah memeriksa, mengadili dan memutus, pertama, perbuatan Badan dan/atau Pejabat Pemerintahan dalam mengeluarkan Keputusan Administrasi Pemerintahan/Keputusan Tata Usaha

${ }^{24}$ Muchsan, Beberapa Catatan Tentang Hukum Administrasi Negara dan Peradilan Administrasi di Indonesia, Liberty, 1981, Yogyakarta, hlm. 18-19.

${ }^{25}$ Ridwan HR, Hukum..., Op. Cit., hlm 119.

${ }^{26}$ Indroharto, Perbuatan..., Op. Cit., hlm 65-66. 
Negara (beschikkingsdaads). Kedua, tindakan Pejabat Pemerintahan atau Penyelenggara Negara lainnya dalam melakukan dan/atau tidak melakukan perbuatan konkret/faktual (materieele daad). Tindakan Pejabat Pemerintahan atau Penyelenggara Negara lainnya dalam melakukan dan/atau tidak melakukan perbuatan konkret/ faktual (materieele daad) dikenal dengan Tindakan Administrasi Pemerintahan (tindakan). Pasal 1 angka 8 Undang-Undang Nomor 30 Tahun 2014 menyebutkan: Tindakan Administrasi Pemerintahan yang selanjutnya disebut tindakan adalah perbuatan Pejabat Pemerintahan atau Penyelenggara Negara lainnya untuk melakukan dan/atau tidak melakukan perbuatan konkret dalam rangka penyelenggaraan pemerintahan.

Bersesuaian dengan asas (fictum positiva) jika waktu yang ditentukan dalam membuat keputusan telah melewati batas waktu yang ditentukan, dan keputusan belum dikeluarkan maka pejabat dianggap mengabulkan, ketentuan Pasal 53 ayat (1, 2, dan 3) Undang-Undang Nomor 30 Tahun 2014 merupakan norma hukum menentukan batas waktu kewajiban bagi Badan dan/atau Pejabat Pemerintahan guna menetapkan Keputusan (KTUN) serta batas waktu kewajiban bagi Pejabat Pemerintahan untuk melakukan suatu Tindakan dalam rangka penyelenggaraan pemerintahan. Jika ketentuan peraturan perundang-undangan tidak menentukan batas waktu kewajiban badandan/atau pejabat pemerintahan, maka badan dan/atau pejabat pemerintahan wajib menetapkan dan/atau melakukan Keputusan dan/atau Tindakan dalam waktu paling lama 10 hari kerja setelah permohonan diterima secara lengkap oleh Badan dan/atau Pejabat Pemerintahan. Apabila dalam batas waktu dimaksud, Badan dan/atau Pejabat Pemerintahan tidak menetapkan Keputusan (KTUN) dan/ atau Pejabat Pemerintahan tidak melakukan suatu tindakan konkret/ faktual, maka permohonan tersebut dianggap dikabulkan secara hukum, dinamakan keputusan fiktif positif.

Dalam Hukum Administrasi Negara, tindakan hukum jabatan pemerintahan dijalankan oleh pejabat pemerintah. Dengan demikian kedudukan hukum pemerintah berdasarkan hukum publik adalah sebagai wakil (vertegenwoordiger) dari jabatan pemerintahan. ${ }^{27}$ Dalam jabatan pemerintahan diberi wewenang untuk melakukan tindakan hukum yakni perbuatan yang menimbulkan akibat hukum atau tindakan yang menimbulkan relevansi hukum atas dasar kewenangan, melalui pejabat (ambtsdrager), sehingga pejabat bertindak untuk dan atas nama jabatan. Pejabat tidak memiliki wewenang, yang memiliki wewenang adalah jabatan, karena pejabat hanya menjalankan tugas dan wewenang.

Badan dan/atau Pejabat Pemerintahan serta Penyelenggara Negara lainnya dalam mengeluarkan Keputusan Administrasi Pemerintahan (KTUN) dan dalam

\footnotetext{
${ }^{27}$ Ridwan, Urgensi..., Op. Cit., hlm. 79.
} 
hal Pejabat Pemerintahan melakukan atau tidak melakukan Tindakan Administrasi Pemerintahan didasarkan pada wewenang (bevoegdheden) yang dimilikinya. Pasal 1 Angka 5 Undang-Undang Nomor 30 Tahun 2014 menyebutkan, Wewenang adalah hak yang dimiliki oleh Badan dan/atau Pejabat Pemerintahan atau Penyelenggara Negara lainnya untuk mengambil keputusan dan/atau tindakan dalam penyelenggaraan pemerintahan. Pasal 1 angka 6 Undang-Undang Nomor 30 Tahun 2014 menyebutkan Kewenangan Pemerintahan yang selanjutnya disebut Kewenangan adalah kekuasaan Badan dan/atau Pejabat Pemerintahan atau Penyelenggara Negara lainnya untuk bertindak dalam ranah hukum publik. Kewenangan (bevoegdheden) melekat pada jabatan (het ambt). Tanpa jabatan tidak ada kewenangan. Jabatan (het ambt) adalah badan (orgaan) hukum publik, merupakan sumber keberadaan kewenangan. Dalam memfungsikan kewenangan yang melekat padanya. Jabatan (hetambt) diwakili oleh manusia pribadi (natuurlijke persoon), lazim disebut Pejabat (ambtsdrager) atau Pejabat Pemerintahan. Badan Pemerintahan adalah wujud badan pemerintahan dalam format kelembagaan, semacam kementerian, instansi/jawatan yang dalam memfungsikan kewenangannya, juga diwakili oleh Pejabat (ambtsdrager).

Hanya Badan dan/atau Pejabat Pemerintahan atau Penyelenggara Negara yang memiliki wewenang, yang dapat mengeluarkan Keputusan Tata Usaha Negara, dan hanya Pejabat Pemerintahan yang berwenang dapat melakukan atau tidak melakukan suatu tindakan konkret/faktual. Oleh karena itu, pada setiap Badan dan/atau Jabatan Pemerintahan ditentukan cakupan bidang atau materi wewenangnya, wilayah atau daerah berlakunya wewenang tersebut serta masa dan tenggang waktu wewenang itu.

Pasal 8 Ayat (2) Undang-Undang Nomor 30 Tahun 2014 mengatur Badan dan/atau Pejabat Pemerintahan dalam menggunakan Wewenang wajib berdasarkan:

a. Peraturan perundang-perundangan; dan

b. AUPB.

Pasal 11 Undang-Undang Nomor 30 Tahun 2014 menetapkan: Kewenangan diperoleh melalui atribusi, delegasi, dan/atau mandat. Menurut Pasal 1 angka 22 Undang-Undang Nomor 30 Tahun 2014 menyebutkan, Atribusi adalah pemberian kewenangan kepada Badan dan/atau Pejabat Pemerintahan oleh UndangUndang Dasar Negara Republik Indonesia Tahun 1945 atau Undang-Undang. Delegasi (Delegation of Authority) adalah pelimpahan kewenangan dari Badan dan/atau Pejabat Pemerintahan yang lebih tinggi kepada Badan dan/atau Pejabat Pemerintahan yang lebih rendah dengan tanggung jawab dan tanggung gugat 
kepada penerima delegasi. Tatkala terjadi pelimpahan kewenangan melalui delegasi, pemberi delegasi kehilangan kewenangan itu. Pelimpahan kewenangan yang diperoleh melalui mandatum, mandataris bertindak untuk dan atas nama mandator. Tanggungjawab dan tanggung gugat tetap berada pada mandator. Dalam melaksanakan wewenangnya, mandataris wajib mencantumkan dirinya selaku pelaksana on behalf of mandator.

Dalam perkembangannya tindakan pemerintahan tidak hanya berdasarkan pada wewenang yang diberikan peraturan perundang-undangan tetapi juga harus memperhatikan hukum tidak tertulis atau asas-asas umum pemerintahan yang baik. Ketentuan Pasal 8 ayat (2) Undang-Undang Nomor 30 Tahun 2014 menyebutkan: Badan dan/atau Pejabat Pemerintahan dalam menggunakan Wewenang wajib berdasarkan:

a. peraturan perundang-perundangan; dan

b. AUPB

Ketika kewenangan itu digunakan tidak sesuai dengan tujuan dilekatkannya kewenangan pada Badan dan/atau Pejabat Pemerintahan berarti terjadi penyalahgunanan wewenang. Pasal 17, Pasal 18 Undang-Undang Nomor 30 Tahun 2014 mengatur Larangan Penyalahgunaan Wewenang

Selanjutnya menurut Indroharto, suatu keputusan dapat dianggap bertentangan dengan peraturan perundang-undangan karena:

a. Badan atau Pejabat Tata Usaha Negara yang bersangkutan mengira memiliki wewenang untuk mengeluarkan atau menolak keputusan padahal sebenarnya ia tidak berwenang untuk berbuat demikian.

b. Berdasarkan peraturan yang bersangkutan memang benar ada wewenang untuk mengeluarkan suatu keputusan, tetapi wewenang tersebut sebenarnya bukan diberikan kepada instansi yang telah mengeluarkan suatu keputusan yang sedang digugat. Hal ini dapat terjadi dalam hal instansi tersebut telah berbuat demikian itu berdasarkan suatu delegasi, dimana sebenarnya delegasi itu tidak didasarkan adanya suatu keputusan pendelegasian dari sang delegans, atau pendelegasian itu sebanarnya tidak boleh dilakukan karena tidak ada dasarnya dalam suatu peraturan.

c. Wewenang yang dimaksud memang ada dasarnya dalam suatu peraturan perundang-undangan, tetapi keputusan yang disengketakan itu sendiri bertentangan dengan peraturan dasarnya tersebut atau bertentangan dengan peraturan perundang-undangan yang lain.

d. Peraturan perundang-undangan yang menjadi dasar dikeluarkannya keputusan yang bersangkutan sebenarnya malah bertentangan dengan peraturan yang lebih tinggi.

e. Keputusan yang disengketakan itu dikeluarkan menyimpang dari peraturan prosedur yang harus ditetapkan. 
Lebih lanjut Indroharto menyebutkan ukuran untuk dapat disebut Badan atau Pejabat Tata Usaha Negara adalah fungsi yang dilaksanakan bukan nama sehari-hari, bukan pula kedudukan strukturalnya dalam salah satu lingkungan kekuasaan negara. Adapun pengelompokan Badan atau Pejabat Tata Usaha Negara yaitu:

1. Instansi-instansi resmi pemerintahan yang berada dibawah Presiden selaku eksekutif.

2. Instansi-instansi dalam lingkungan negara di luar lingkungan kekuasaan eksekutif yang berdasarkan peraturan perundang-undangan melaksanakan urusan pemerintahan.

3. Badan-badan hukum perdata yang didirikan oleh pemerintahan dengan maksud untuk melaksanakan urusan pemerintahan.

4. Instansi-instansi yang merupakan kerjasama antara pihak pemerintah dengan pihak swasta yang melaksanakan tugas pemerintahan.

5. Lembaga-lembaga hukum swasta yang berdasarkan peraturan perundang-undangan dan sistem perizinan melaksanakan tugas pemerintahan. ${ }^{28}$

Selanjutnya pada ketentuan Pasal 4 Undang-Undang Nomor 30 Tahun 2014 menyebutkan bahwa ruang lingkup pengaturan Administrasi Pemerintahan meliputi semua aktivitas:

1. Badandan/atau Pejabat Pemerintahan yang menyelenggarakan Fungsi Pemerintahan dalam lingkup lembaga eksekutif;

2. Badan dan/atau Pejabat Pemerintahan yang menyelenggakan Fungsi Pemerintahan dalam lingkup lembaga yudikatif;

3. Badan dan/atau Pejabat Pemerintahan yang menyelenggarakan Fungsi Pemerintahan dalam lingkup lembaga legislatif;

4. Badan dan/atau Pejabat Pemerintahan lainnya yang menyelenggarakan Fungsi Pemerintahan yang disebutkan Undang-Undang Dasar Negara Republik Indonesia Tahun 1945dan/atau undang-undang.

Sedangkan suatu urusan itu akan menjadi urusan pemerintahan ketika terpenuhi ketiga kriteria ini:

1. Urusan itu merupakan bidang publik atau menyangkut kepentingan umum (algemeen belang);

2. Ada intervensi atau keterlibatan pemerintah secara langsung atau tidak langsung dalam urusan tersebut;

3. Peraturan perundang-undangan memberikan wewenang kepada pemerintah untuk mengurus (besturen) dan mengatur (regelen) urusan tersebut. ${ }^{29}$ 


\section{Pengujian Keputusan Fiktif Positif di Pengadilan Tata Usaha Negara}

Pengujian keputusan fiktif positif oleh hakim di Pengadilan Tata Usaha Negara dapat diketahui melalui putusan pengadilan tata usaha negara. Menurut Soehartono ${ }^{30}$ pengujian yang dilakukan oleh Hakim Pengadilan Tata Usaha Negara secara das sollen adalah sebatas yang ditentukan dalam Pasal 53 ayat (2) mengenai penerapan hukum yang dilakukan oleh pemerintah dalam melakukan tindakan hukum Tata Usaha Negara dari aspek hukumnya (rechmatigheid). Menurut Indroharto ${ }^{31}$, pengujian dari segi hukum peradilan tata usaha negara meliputi unsur-unsur pokok:

1. Pengujian mengenai kewenangan Badan atau Jabatan Tata Usaha Negara pada waktu mengeluarkan keputusan yang disengketakan meliputi: Onbevoegheid ratione materiae, Onbevoegheid ratione loci, dan Onbevoegheid ratione temporis.

2. Pengujian yang bersifat formal yaitu yang berkaitan dengan soal apakah pembentukan keputusan tersebut telah memenuhi prosedur yang telah ditentukan.

3. Pengujian yang bersifat formal yang menyangkut soal rumusan dalam putusan sudah cukup jelas/tidak jelas.

4. Pengujian secara materiil dalam arti apakah isi dari keputusan yang disengketakan ini telah sesuai dengan norma-norma hukum materiil yang berlaku.

5. Pengujian secara materiil berarti pula apakah keputusan yang disengketakan didasarkan pada peraturan perundang-undangan yang tidak bertentangan dengan peraturan yang lebih tinggi. ${ }^{32}$

Menurut Ridwan tolok ukur pengujian Keputusan Tata Usaha Negara adalah berpedoman pada Pasal 53 ayat (2) Undang-Undang Nomor 51 Tahun 2009 tentang Perubahan Kedua Atas Undang-Undang Nomor 5 Tahun 1986 tentang Peradilan Tata Usaha Negara yaitu:

a. Keputusan Tata Usaha Negara yang digugat itu bertentangan dengan peraturan perundang-undangan yang berlaku.

b. Keputusan Tata Usaha Negara yang digugatitu bertentangandengan asas-asas umum pemerintahan yang baik (AUPB). ${ }^{33}$

Pasal 16 Peraturan Mahkamah Agung RI Nomor 8 Tahun 2017 menyebutkan dasar Putusan atas penerimaan permohonan adalah menguji kewenangan

\footnotetext{
${ }^{29}$ Ridwan, Tiga ..., Op. Cit., hlm. 40.

${ }^{30}$ Soehartono, "Membangun Konstruksi Penemuan Hukum Oleh Hakim Dalam Penyelesaian Sengketa Tata Usaha Negara", Disertasi, Universitas Sebelas Maret, Surakarta, 2012, hlm. 13.

${ }^{31}$ Indroharto, Usaha Memahami Undang-Undang Peradilan Tata Usaha Negara, Pustaka Sinar Harapan,Jakarta, 1993, hlm. 168.

32Ibid., hlm. 168.

${ }^{33}$ Ridwan, Tiga Dimensi..., Op. Cit., hlm. 174-175.
} 
pengadilan sebagaimana dimaksud dalam Pasal 53 Undang-Undang Nomor 30 Tahun 2014 dan kedudukan hukum pemohon juga menguji kewenangan badan atau pejabat pemerintahan,menguji prosedur dan/ atau substansi penerbitan keputusan dan/atau tindakan fiktif positif berdasarkan peraturanperundangundangan.

Sedangkan Objek permohonan dalam Ketentuan Pasal 3 ayat (1) Perma Nomor 8 Tahun 2017 adalah kewajiban badan dan/ atau pejabat pemerintahan untuk menetapkan keputusan dan/atau melakukan tindakan administrasi pemerintahan yang dimohonkan sesuai dengan ketentuan peraturan perundangundangan.

Pasal 3 ayat (1) Perma Nomor 8 Tahun 2017, tidak termasuk objek permohonan yang dapat diajukan ke Pengadilan sebagai berikut:

a. Permohonan merupakan pelaksanaan dari putusan pengadilan yang berkekuatan hukum tetap.

b. Permohonan terhadap permasalahan hukum yang sudah pernah diajukan gugatan.

Pengujian dari segiformalitas permohonan meliputi pengujian objek permohonan dari aspek kewenangan Pengadilan, Tenggang waktu pengajuan permohonan dan Kepentingan Pemohon; dan PengujianPokok Permohonan yaitu Kewenangan, Prosedur dan substansi permohonan.

Pengujian dari segi kewenangan Pengadilan, apakah permohonan Pemohon masuk dalam kriteria permohonan sebagaimana dimaksud Pasal 3 ayat (2) Perma No. 8 Tahun 2017, yaitu:

a. Permohonan dalam lingkup kewenangan badan dan/atau pejabat pemerintahan;

b. Permohonan terhadap keputusan dan/atau tindakan untuk menyelenggarakan fungsi pemerintahan;

c. Permohonan terhadap keputusan dan/atau tindakan yang belum pernah ditetapkan dan/atau dilakukan oleh badan dan/atau pejabat pemerintahan

d. Permohonan untuk kepentingan pemohon secara langsung.

Pengujian kriteria permohonan pada Pasal 3 ayat (2) Perma No. 8 Tahun 2017 bersifat kumulatif artinya semua permohonan yang diajukan kepada Termohon harus memenuhi ketentuan tersebut, tidak terpenuhinya salah satu kriteria berakibat hukum Pengadilan Tata Usaha Negara tidak berwenang untuk memeriksa, memutus dan menyelesaikan permohonan, dengan amar putusan Permohonan Pemohon tidak diterima dan dihukum untuk membayar biaya perkara. 
Pengujian Tenggang waktu pengajuan permohonan guna mendapatkan keputusan dan atau tindakan badan atau pejabat pemerintahan, hanya dapat diajukan 90 hari kalender sejak:

a. Batas waktu kewajiban badan atau pejabat pemerintahan untuk menetapkan dan/atau melaksanakan Keputusan dan/atau Tindakan sesuai dengan ketentuan peraturan perundang-undangan terlampaui; atau

b. Setelah 10 hari kerja permohonan diterima secara lengkap oleh Badan dan/atau Pejabat Pemerintahan, jika batas waktu kewajiban untuk menetapkan dan/atau melakukan keputusan dan/atau tindakan tidak diatur dalam peraturan perundang-undangan.

Selanjutnya pengujian obyek permohonan dari segi kewenangan, prosedur dan substansi. Pengujian dari segi kewenangan, merupakan pengujian hukum terhadap kewenangan yang ada pada badan dan/atau pejabat pemerintahan. PTUN menilai dari segi kewenangan yang melekat pada badan dan/atau pejabat pemerintahan berdasarkan peraturan perundang-undangan yang berlaku dengan melakukan penilaian apakah badan dan/atau pejabat pemerintahan melaksanakan wewenangnya berdasarkan peraturan perundang-undangan, apakah badan dan/atau pejabat pemerintahan memiliki kewenangan menerbitkan objek sengketa, kemudian termasuk kriteria wewenang apa yang ada dalam badan dan/atau pejabat pemerintahan

Pengujian dari segi prosedur, mengenai prosedur yang harus dijalankan Termohon terhadap diterimanya permohonan dan persyaratan yang dinyatakan lengkap. Berdasarkan ketentuan Pasal 53 ayat (1 dan 2) Undang-Undang Nomor 30 Tahun 2014, prosedur yang harus dijalankan Termohon adalah menjawab permohonan Pemohon sesuai dengan peraturan perundang-undangan/ 10 hari kerja sejak permohonan diterima secara lengkap oleh Termohon, dan Termohon tidak menjawab permohonan Pemohon melebihi 10 hari, maka Termohon sudah melalaikan kewajibannya, berarti Termohon sudah melanggar prosedur yang telah diatur dalam peraturan perundang-undangan, namun tidak berarti mengabulkan permohonan pemohon, karena dikabulkan atau tidaknya permohonan tergantung dari kelengkapan persyaratan yang diwajibkan kepada pemohon sesuai dengan peraturan perundang-undangan yang berlaku.Pengujian dari segi substansi, adalah suatu wewenang untuk menilai apakah keputusan fiktif positif/tindakan fiktif positif sesuai dengan peraturan perundang-undangan dan apakah Termohon tersebut berwenang mengeluarkan keputusan keputusan fiktif positif/tindakan fiktif positif. 


\section{Penutup}

Kriteria tindakan fiktif positif Badan dan/atau Pejabat Pemerintahan berkaitan dengan sikap diam atau abainya kewajiban hukum Badan dan/atau Pejabat Pemerintahan untuk menjawab permohonan yang diajukan oleh seseorang atau badan hukum perdata, terkait dengan tugas, fungsi, dan kewenangan Badan dan/atau Pejabat Pemerintahan dengan tidak menetapkan keputusan (KTUN) dan/atau tidak melakukan tindakan dalam rangka penyelenggaraan pemerintahan sesuai ketentuan peraturan perundang-undangan dalam batas waktu kewajiban yang diatur dalam peraturan perundang-undangan atau jika peraturan perundang-undangan tidak mengaturnya setelah 10 hari kerja sejak permohonan diterima secara lengkap, maka permohonan dianggap dikabulkan secara hukum, sebagaimana dimaksud pada Pasal 53 ayat (1, 2, dan 3) Undang-Undang Nomor 30 Tahun 2014, dan keputusannya disebut keputusan fiktif positif. Sedangkan terkait materi permohonan yang diajukan kepada Badan dan/atau Pejabat Pemerintahan diatur dalam ketentuan Pasal 3 Peraturan Mahkamah Agung Republik Indonesia Nomor 8 Tahun 2017.

Dalam kaitannya dengan ketentuan Pasal 53 Undang-Undang Nomor 30 Tahun 2014, Pengadilan Tata Usaha Negaradiberi kewenangan untuk menguji keputusan fiktif positif dengan menggunakan peraturan perundang-undangan yang berlaku dan azas-azas umum pemerintahan yang baik dan hukum acaranya diatur dalam Peraturan Mahkamah Agung RI Nomor 8 Tahun 2017.

\section{Daftar Pustaka}

\section{Buku}

Basah, Sjachran, Eksistensi dan Tolok Ukur Badan Peradilan Administrasi Negara Republik Indonesia, Alumni, Bandung, 1985.

E Owen, Hughes, Public Managemen and Administration, An Introduction, Martin's Press, London, UK, 1994.

Indroharto, UsahaMemahami Undang-Undang Tentang Peradilan Tata Usaha Negara, Buku I, Ghalia Indonesia, Sinar Harapan, Jakarta, 1993.

Perbuatan Pemerintah Menurut Hukum Publik Dan Hukum Perdata, LPP HAN, Jakarta, 1999.

Muchsan, Beberapa Catatan Tentang Hukum Administrasi Negara dan Peradilan Administrsi di Indonesia, Liberty, Yogyakarta, 1981.

Manan, Bagir, Perkembangan UUD 1945, FH UII Press, Yogyakarta, 2004.

Ridwan HR., Hukum Administrasi Negara, FH UII Press, Yogyakarta, 2003. 
HukumAdministrasi Negara, Edisi Revisi, PT. Raja Grafindo Persada, Jakarta, 2010.

Urgensi Upaya Administrasi Di Indonesia, Cetakan Pertama, FH UII Press, Yogyakarta, 2019.

Diskresi dan Tanggungjawab Pemerintah, FH UII Press, Yogyakarta, 2014.

Tiga Dimensi Hukum Administrasi dan Peradilan Administrasi, UII Press, Yogyakarta, 2009.

Simanjuntak, Enrico, Hukum Acara Peradilan Tata Usaha Negara, Transformasi dan Refleksi, Sinar Grafika, Jakarta, 2018.

\section{Jurnal}

Kartika Widya Utama, "Surat Keputusan Tata Usah Negara Yang Bersifat Fiktif Positif", Jurnal Notarius, Edisi 08 Nomor 2, September 2015.

\section{Disertasi}

Soehartono, "Membangun Konstruksi Penemuan Hukum Oleh Hakim Dalam Penyelesaian Sengketa Tata Usaha Negara", Disertasi, Universitas Sebelas Maret, Surakarta, 2012.

\section{Perundang-undangan}

Undang-Undang Dasar Negara Republik Indonesia Tahun 1945

Undang undang Nomor 3 Tahun 2009 tentang Mahkamah Agung.

Undang undang Nomor 48 Tahun 2009 tentang Kekuasaan Kehakiman.

Undang-Undang Nomor 5 Tahun 1986 tentang Peradilan Tata Usaha Negara.

Undang-Undang Nomor 9 Tahun 2004 tentang Perubahan Atas Undang-undang Nomor 5 Tahun 1986 tentang Peradilan Tata Usaha Negara.

Undang-Undang Nomor 51 Tahun 2009 tentang Perubahan Kedua atas UndangUndang Nomor 5 Tahun 1986 tentang Peradilan Tata Usaha Negara.

Undang-Undang Nomor 30 Tahun 2014 tentang Administrasi Pemerintahan.

Peraturan Mahkamah Agung Republik Indonesia Nomor 8 Tahun 2017 tentang Pedoman Beracara Untuk Memperoleh Putusan Atas Penerimaan Permohonan Guna Mendapatkan Keputusan Dan/ Atau Tindakan Badan Atau Pejabat Pemerintahan.

\section{Putusan}

Putusan Mahkamah Konstitusi Republik Indonesia, Nomor 77/PUU-XV / 2017.

Putusan Nomor: 175/ PK/TUN/2016.

Putusan Nomor: 19/P/FP/2016/PTUN.PLK

Putusan Nomor: 10/P/FP/PTUN.SMD

Yurisprudensi Peradilan Administrasi Perancis: Keputusan Implisit dan Titik Singgung Antara Sanksi Pidana dan Sanksi Administrasi. 